\title{
FIRST RESULTS ABOUT TOPOISOMERASE ACTIVITY IN ASTACUS ASTACUS AND AUSTROPOTAMOBIUS PALLIPES AS A BIOMARKER FOR CRAYFISH VIABILITY
}

\author{
M. PAOLUCCI, C. DI CRISTO, C. LIBERATO, A. DI COSMO
}

Dept of Biological and Environmental Sciences. Faculty of Sciences. University of Sannio. Via Port'Arsa, 11. 82100 Benevento - Italy.

E-Mail: paolucci@unisannio.it

Reçu le 6 janvier 2004

Accepté le 4 mai 2004

Received January 6, 2004

Accepted May 4, 2004

\begin{abstract}
A comparative study of topoisomerase activity in two European crayfish species Astacus astacus and Austropotamobius pallipes was carried out to determine the physiological basis of the difference in ecological fitness of these systematically related crayfish species. Topoisomerase activity was present in both species. Adult males were kept for a week at the temperatures of 4,15 and $25^{\circ} \mathrm{C}$. Topoisomerase activity was measured in the hepatopancreas, the muscle tissue and the spermiducts. It was present in the hepatopancreas of Atacus astacus at the three tested temperatures and in Austropotamobius pallipes only at the temperatures of 4 and $15^{\circ} \mathrm{C}$. No topoisomerase activity was registered in the muscle tissue and in the spermiducts. Taken together these data indicate that topoisomerase activity can be a useful marker for crayfish viability.
\end{abstract}

Key-words: topoisomerase, Astacus astacus, Austropotamobius pallipes, hepatopancreas.

\section{RÉSULTATS PRÉLIMINAIRES SUR L'ACTIVITÉ DE LA TOPOISOMÉRASE EN TANT QUE BIOMARQUEUR DE VIABILITÉ CHEZ ASTACUS ASTACUS ET AUSTROPOTAMOBIUS PALLIPES}

\section{RÉSUMÉ}

Une étude comparative de l'activité de la topoisomérase chez deux espèces d'écrevisses européennes, Astacus astacus et Austropotamobius pallipes, a été réalisée pour étudier l'aspect physiologique en ce qui concerne leurs différences écologiques. L'activité de la topoisomérase a été révélée chez les deux espèces. Les mâles adultes ont été gardés pendant une semaine aux températures de $4^{\circ} \mathrm{C}, 15^{\circ} \mathrm{C}$ et $25^{\circ} \mathrm{C}$. L'activité de la topoisomérase a été recherchée dans l'hépatopancréas, le tissu musculaire et le spermiducte. Elle est présente dans l'hépatopancréas d'Astacus astacus aux trois températures testées et chez Austropotamobius pallipes aux températures de $4{ }^{\circ} \mathrm{C}$ et $15^{\circ} \mathrm{C}$. Aucune activité n'a été révélée dans le tissu musculaire et dans le spermiducte. L'ensemble de ces données montre que l'activité de la topoisomérase peut être un bon marqueur pour tester la viabilité des écrevisses.

Mots-clés : topoisomérase, Astacus astacus, Austropotamobius pallipes, hépatopancréas. 


\section{INTRODUCTION}

Topological manipulation is a fundamental aspect of DNA functional activities such as recombination, replication and transcription. All DNA synthetic activities require the double strands to be separated. However, in order to carry on their separation, the DNA strands have to rotate one around the other. There are specific enzymes named topoisomerases that catalyze such a reaction. Some topoisomerases are able to relax the DNA double strands which are either negatively, or negatively and positively supercoiled. Some other topoisomerases can cause DNA double strands to be either negatively (bacteric DNA girase) or positively (inverse girase) supercoiled (CHAMPOUX, 2001). Topoisomerase activity is positively regulated by a protein chinase $C$, throughout a phosphorilation mechanism (SAYONN et al., 1986; SAMUELS et al., 1989; POMMIER et al., 1990). Topoisomerases are classified into two groups according to their mechanism of action. Type I topoisomerase causes transient breakthrough in one of the two DNA strands, and is subdivided into type IA and type IB subfamilies according to the site of link, which can be the terminal 5' or 3' respectively. On the other hand, type II topoisomerase can cut both DNA strands. Recently, BULHER et al. (1998) discovered a new type II topoisomerase in the archeobacter Sulfolobus shibatae; therefore type II topoisomerase has been divided into the subfamilies IIA and IIB.

It has been demonstrated that exposure to environmental stimuli results in modifications of DNA arrangement. In mesofili bacteria the number of DNA links increases after heat-shock exposure and decreases after cold-shock (LOPEZ-GARCIA and FORTERRE, 1999); moreover osmotic shock causes an increase in the DNA supercoiling tension (MCCLENNAN et al., 1990). When DNA is excessively supercoiled it becomes inaccessible to the enzymes responsible for replication and transcription. Studies carried out on murine cells pointed out that DNA replication is inhibited by heat stress (CIAVARRA and GOLMANN, 1994). Since replication and transcription are both vital processes in all organisms, their inhibition would result in death; thus it is likely that topoisomerase enzymes, responsible for DNA arrangement, play a pivotal role during exposure to stressful events. Crayfish are exposed to various stress factors in their natural environment. Among these are short or long term exposures to temperature changes. Changes in temperature occur naturally, but may also occur as a result of environmental pollution. The impact of temperature changes on the viability of crayfish is of particular interest, since this parameter affects all metabolic processes. In Europe crayfish populations have been dramatically declining over the last few decades, due to both natural causes and environmental degradation as a consequence of human activity. In this study we have employed two species of freshwater crayfish: Astacus astacus and Austropotamobius pallipes. The aim of the present study was to investigate the role of topoisomerase enzymes, as biochemical parameters that would reflect the different adaptability of crayfish species. Topoisomerase activity has been evaluated in the hepatopancreas, muscle tissue and spermiduct of animals kept at three different temperatures, 4,15 and $25^{\circ} \mathrm{C}$.

\section{MATERIALS AND METHODS}

\section{Animals}

Adult males $(n=12)$ for each species of crayfish of similar total body length and with spermiducts containing sperm cells were used. Specimens of Astacus astacus were purchased at the "First Bavarian Crayfish Hatchery" (Augsburg, Germany). Specimens of Austropotamobius pallipes were collected in the river Sassinoro, which belongs to the Morcone municipality, situated in the district of Benevento (Campania region, South of Italy). Upon arrival animals were transferred to the laboratory and acclimated in tanks of approximately $100 \mathrm{I}$ each, with a recirculating water system and natural circadian rhythm. Normal water quality parameters were monitored during all the duration of the experiment. 
Animals were fed three times a week ad libitum and uneaten food was promptly removed. The acclimation period lasted ten days at a temperature of $15^{\circ} \mathrm{C}$.

The temperature trial was conducted in the laboratory using a system of 6 tanks which were set up as follows: two tanks were set at $4^{\circ} \mathrm{C}$, two tanks at $15^{\circ} \mathrm{C}$ and two tanks at $25^{\circ} \mathrm{C}$. For each species, animals were divided into three groups of four individuals each and kept in tanks set at the three temperatures of 4,15 , and $25^{\circ} \mathrm{C}$. The trial lasted a week.

\section{Tissue extract preparation}

Animals were sacrificed after anesthesia on ice. Hepatopancreas, muscle tissue (from the tail) and spermiducts were removed. Samples were weighed separately, minced and diluted with homogenization buffer $\left(50 \mathrm{mM}\right.$ Tris- $\mathrm{HCl}, 0.5 \mathrm{M} \mathrm{NaCl}, 20 \mathrm{mM} \mathrm{MgCl}_{2}$, $\mathrm{pH}$ 7.6) at a dilution of 1:2 (wt/vol), then homogenized in ice with a rotating homogenizer Polytron. Samples were then centrifuged at a $15000 \mathrm{rpm}$, for $1 \mathrm{hr}$ at $4^{\circ} \mathrm{C}$. The supernatant obtained was collected and added with ammonium sulfate at a final concentration of $20 \%$. The sample was incubated on ice for 30 min with continuous stirring. It was then centrifuged at $15000 \mathrm{rpm}$ for $1 \mathrm{~h}$ at $4^{\circ} \mathrm{C}$. The supernatant was collected and added with ammonium sulfate at a final concentration of $70 \%$. The solution was incubated on ice for $30 \mathrm{~min}$ and stirred continuously, then centrifuged at $15000 \mathrm{rpm}$ for $1 \mathrm{hr}$ at $4^{\circ} \mathrm{C}$. The supernatant was discharged while the pellet was collected and resuspended in $2 \mathrm{ml}$ of homogenization buffer. The sample was dialyzed for $24 \mathrm{~h}$ at $4^{\circ} \mathrm{C}$, under stirring and with frequent changes. This sample is indicated as cytoplasmic extract. The total protein content of the cytoplasmic extract was measured according to the Bradford method (protein assay BIORAD).

\section{Topoisomerase I and II activity evaluation}

Topoisomerase I and II differ one from the other on the basis of their dependency on ATP. Topoisomerase I activity is ATP-independent, while topoisomerase II activity is ATP dependent. The evaluation of topoisomerase II activity was carried out as described for topoisomerase I except that the incubation buffer contained $30 \mu$ of ATP.

\section{Topoisomerase activity evaluation}

Topoisomerase activity was measured on the basis of its capacity to modify the DNA topological arrangement of the plasmidic DNA (pBR322). For in vivo measurement of topoisomerase activity, tissue extracts (hepatopancreas, muscle tissue and spermiduct) obtained from animals kept at different temperatures were incubated with aliquots of plasmidic DNA (pBR322). Cytoplasmic extracts were incubated in incubation buffer $(2 \mu \mathrm{l}$ of $\beta$ Mercaptoethanol $+5 \mu$ l of BSA in $0.15 \mathrm{M}$ Tris- $\mathrm{HCl}, 0.3 \mathrm{M} \mathrm{KCl}, 0.06 \mathrm{M} \mathrm{MgCl}_{2} \mathrm{pH} 7.5$ ) with an aliquot of plasmidic DNA (pBR322) in a ratio of protein/DNA of 8 , for $30 \mathrm{~min}$. at $4^{\circ} \mathrm{C}$ for those animals kept at $4^{\circ} \mathrm{C}$, at $15^{\circ} \mathrm{C}$ for those animals kept at $15^{\circ} \mathrm{C}$ and at $25^{\circ} \mathrm{C}$ for those animals kept at $25^{\circ} \mathrm{C}$. The incubation was stopped by the addition of phenolchloroform followed by a centrifugation at $12000 \mathrm{rpm}$ for $2 \mathrm{hrs}$ at $4^{\circ} \mathrm{C}$. The supernatant was collected and added with absolute ethanol and centrifuged at $12000 \mathrm{rpm}$ for $5 \mathrm{~min}$. at $4^{\circ} \mathrm{C}$. The supernatant was discharged and the pellet collected and suspended in $200 \mu \mathrm{l}$ of $70 \%$ ethanol. The sample was centrifuged again at $12000 \mathrm{rpm}$ for $5 \mathrm{~min}$ at $4^{\circ} \mathrm{C}$. The supernatant was discharged and the pellet resuspended in $25 \mu$ of TE buffer ( $1 \mathrm{M}$ Tris, 0.5 M EDTA, pH 8.0).

Samples were then run on $1 \%$ agarose gel without ethidium bromide for $1 \mathrm{hr}$. At the end of the run gels were soaked in TBE buffer (0.045 M Tris-borate, $0.001 \mathrm{M}$ EDTA $\mathrm{pH}$ 8) plus $3 \mu \mathrm{l}$ of ethidium bromide. Gels were then analyzed with a Molecular Imager FX' (Biorad). Band presence and size (in bp) were calculated with the software "Quantity One". 
For in vitro measurement of topoisomerase activity, tissue extracts (hepatopancreas, muscle tissue and spermiduct) were incubated at different temperatures with aliquots of plasmidic DNA (pBR322). Cytoplasmic extracts from animals kept at $15^{\circ} \mathrm{C}$, were incubated with an aliquot of plasmidic DNA (pBR322) at $4,15,25,30$ and $36^{\circ} \mathrm{C}$. The following steps were the same as previously described for in vivo topoisomerase activity.

\section{RESULTS}

The plasmid pBR322 DNA is present into two forms with different electrophoretic mobility: the supercoiled form which runs much faster than the circular form. When present topoisomerase enzymes bring about the relaxation of the supercoiled form into the circular form, with consequent retardation of electrophoretic mobility.

\section{Characterization of topoisomerase I and II activity.}

When topoisomerase activity was present, no differences were observed in either presence or absence of ATP. Therefore the following results refer to topoisomerase I if not specified otherwise.

In vitro topoisomerase activity. Samples of hepatopancreas extract of Astacus astacus and Austropotamobius pallipes were incubated at different temperatures, ranging from 4 to $36^{\circ} \mathrm{C}$. The best temperatures for topoisomerase activity were 4 and $15^{\circ} \mathrm{C}$ (Figure 1).

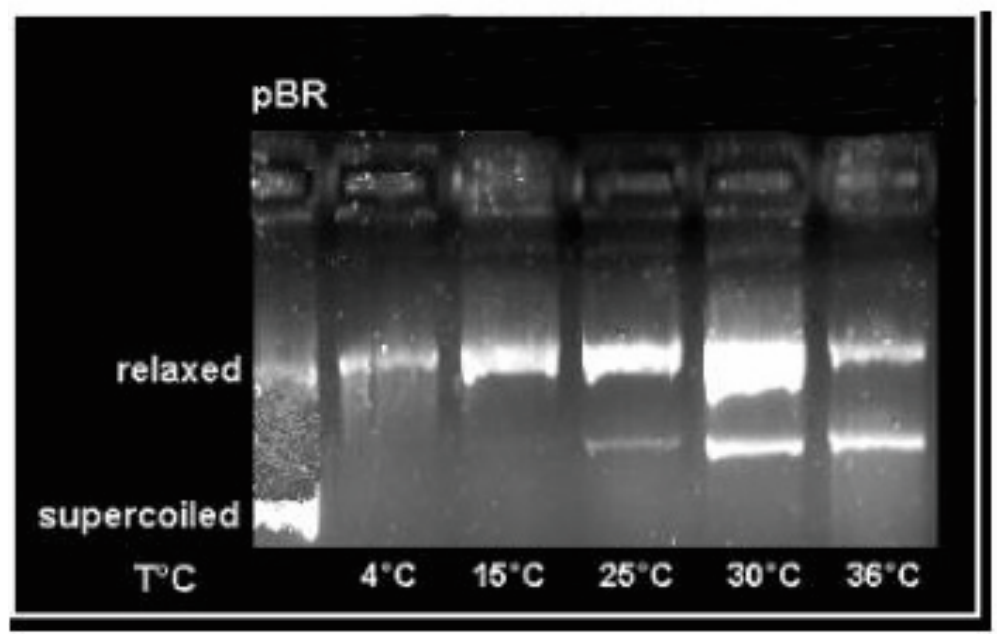

Figure 1

In Vitro topoisomerase activity of the hepatopancreas extracts of Astacus astacus tested at different temperatures. Austropotamobius pallipes gave similar results.

\section{Figure 1}

Activité in vitro de la topoisomérase à partir d'extraits d'hépatopancréas chez Astacus astacus soumises à différentes températures. Chez Austropotamobius pallipes, les résultats sont identiques.

\section{In vivo topoisomerase activity}

In the hepatopancreas topoisomerase activity was present in Astacus astacus at the temperatures of 4,15 and $25^{\circ} \mathrm{C}$, and in Austropotamobius pallipes at the temperatures of 4 and $15^{\circ} \mathrm{C}$ (Figure 2). No topoisomerase activity was present in the muscle tissue and in the spermiduct. 


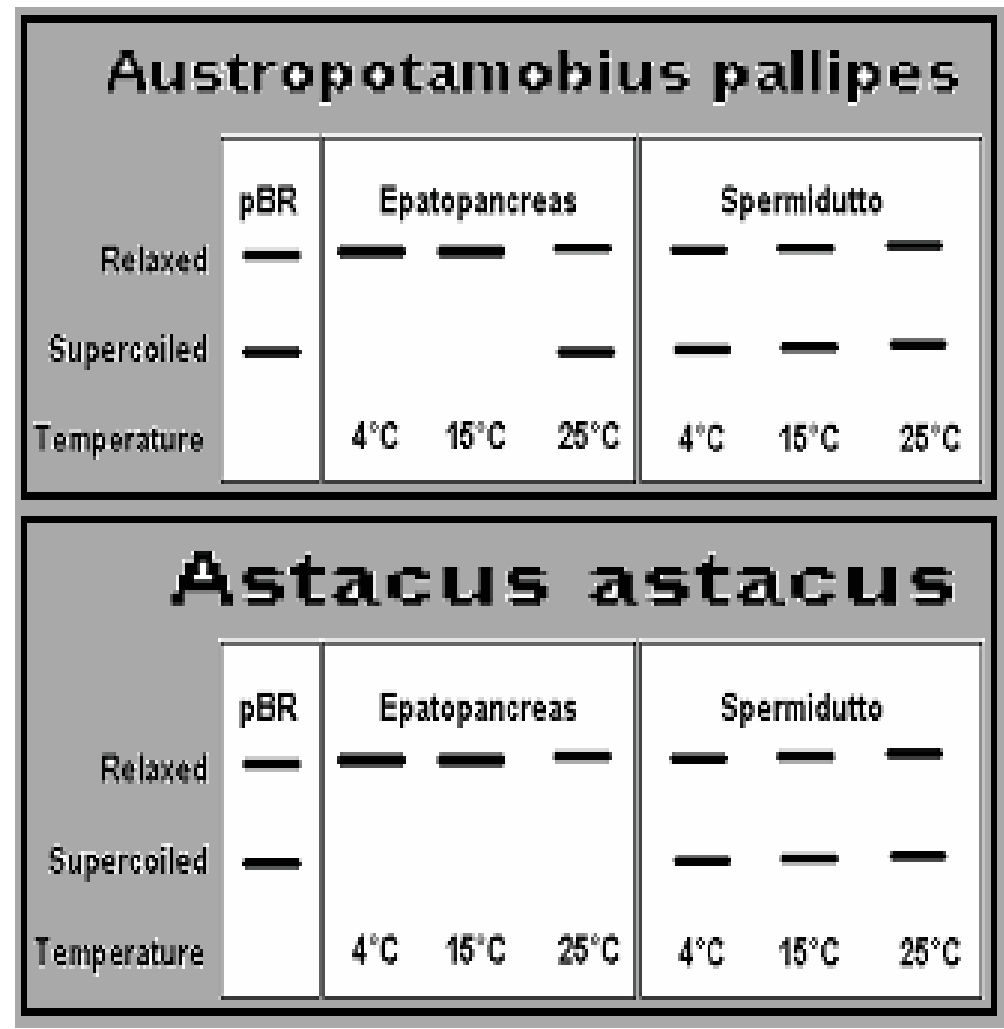

Figure 2

Drawing of the comparative distribution of topoisomerase activity in the hepatopancreas and spermiduct of Astacus astacus and Austropotamobius pallipes kept at different temperatures.

Figure 2

Distribution de l'activité de la topoisomérase dans l'hépatopancréas et le spermiducte d'Astacus astacus et d'Austropotamobius pallipes maintenues à différentes températures.

\section{DISCUSSION}

It is today worldwide recognized that the term "stress" indicates a condition in which an organism is exposed to both external and internal stimuli (stressors), leading to an alteration of the equilibrium, and that with the term "reaction to stress" a series of non-specific responses of the organism to stressors are indicated. In other words, the reaction to stress is a series of physiological reactions that takes place whenever an organism must adapt to a new situation. Changes in DNA topology constitute an essential mechanism of adaptation during environmental stress. DNA topological control involves the topoisomerase activity. Nothing is known about whether or not topoisomerase are involved in the response to stressors in crayfish, although topoisomerase I presence has been reported in the shrimps Penaeus japonicus and Artemia franciscana (CARETTONI et al., 1994; CHUANG et al., 1996). In the present study, we have detected, for the first time in crayfish, the presence and the activity of topoisomerase. Moreover, topoisomerase activity has been monitored both in vivo and in vitro at different temperatures. Our results did not show any difference in topoisomerase activity in the presence or absence of ATP. Topoisomerase I and topoisomerase II show overlapping functions. Genetic analysis suggests that topoisomerase II has a function that overlaps with that of topoisomerase I in 
the essential processes (GOTO and WANG, 1985; UEMURA et al., 1987). Topoisomerase I and II differ one from the other in their dependency on ATP. Indeed, topoisomerase II, that catalyzes different DNA isomerization reactions, is dependent on the hydrolysis of adenosine triphosphate (ATP) (COZZARELLI, 1980; LIU et al., 1980; SANDER and HSIEH, 1983; WANG, 1987). In our experiments, ATP presence in the incubation buffer did not change topoisomerase activity, therefore topoisomerase activity can be ascribed to topoisomerase I and in the following discussion we will refer to it as topoisomerase activity. In vitro experiments revealed that topoisomerase activity was at its best at 4 and $15^{\circ} \mathrm{C}$, in good agreement with the results of the in vivo experiments. When animals were kept at different temperatures (in vivo experiments), the results were slightly different between the species. Topoisomerase activity was detected in the hepatopancreas of Astacus astacus kept at 4,15 and $25^{\circ} \mathrm{C}$, while it was present in the hepatopancreas of Austropotamobius pallipes kept at $4^{\circ} \mathrm{C}$ and $15^{\circ} \mathrm{C}$. These results are not surprising since these are the ranges of temperatures considered physiological for the species. Moreover, these results are in agreement with the topoisomerase functions investigated in other invertebrates, such as Drosophila melanogaster, where topoisomerase I is actively involved in the transcription process of the adult (FLEISCHMANN et al., 1984; GILMOUR et al., 1986; GILMOUR and ELGIN, 1987) and during the developmental stages (ZHANG et al., 2000). No topoisomerase activity was found either in the spermiduct or in the muscle tissue at any of the tested temperatures. Studies carried out in vertebrates show that topoisomerase II is characteristic of testis (GALANDE and MUNIYAPPA, 1996). A number of studies have shown in yeast that DNA topoisomerase II is essential for chromosome condensation and disjunction during mitosis at the metaphase/anaphase transition and meiosis (ROSE et al., 1990). During rat spermatogenesis expression of topoisomerase II was restricted to spermatogonia, spermatocytes and round and early-elongating spermatids (CHEN and LONG, 1996). Topoisomerase II activity was present in rooster spermatids, but not in sperm (ROCA and MEZQUITA; 1989). Although speculative we can hypothesize that also in crayfish topoisomerase activity is not present in sperm cells. No topoisomerase activity was found in the muscle tissue either. Unfortunately, we do not have any explanation for such result apart from hypothesizing that transcription processes are not high in this tissue.

To conclude, our data indicate that topoisomerase activity can be ascribed to type I topoisomerase and it is at its best at the temperature considered physiological in Astacus astacus and Austropotamobius pallipes. It is indicative indeed that no topoisomerase activity was detected at a temperature of $25^{\circ} \mathrm{C}$ in Austropotamobius pallipes, which is well known for its intolerance to high temperatures. On the other hand, topoisomerase activity was present in Astacus astacus kept at $25^{\circ} \mathrm{C}$, further sustaining that this is a viable temperature for this species.

Taken together these data indicate that topoisomerase activity can be a useful marker for crayfish viability. This is particularly relevant especially for crayfish farming to evaluate how animals respond to environmental stressors such as changes in temperature.

\section{AKNOWLEDGMENT}

This study was supported by a grant to Marina Paolucci by the Regione Campania, Settore Foreste, Caccia e Pesca (L.R. 42/87).

\section{REFERENCES}

BULHER C., GADELLE D., FORTERRE P., WANG J.C., BERGERAT A., 1998. Reconstitution of DNA topoisomerase $\mathrm{VI}$ of the thermophilic archaeon Sulfolobus shibatae from subunits separately overexpressed in Escherichia coli. Nucleic Acids Res., 26, 5157-5162. 
CARETTONI D., LANDSBERGER N., ZAGNI E., BENFANTE R., BADARACCO G., 1994. Topoisomerase I action on the heterochromatic DNA from the brine shrimp Artemia franciscana: studies in vivo and in vitro. Biochem J., 299, 623-629.

CHAMPOUX J.J., 2001. DNA topoisomerases: structure, function, and mechanism. Annu. Rev. Biochem., 70, 369-413.

CHEN J.-L., LONG F.J., 1996. Expression and localization of DNA topoisomerase II during rat spermatogenesis. Mol. Reprod. and Develop., 45, 61-71.

CHUANG N.-N., LIN C.-L., CHEN H.-K., 1996. Modification of DANN topoisomerase I enzymatic activity with phosphotyrosyl protein phosphatase and alkaline phosphatase from the hepatopancreas of the shrimp Penaeus japonicus (Crustacea: decapoda). Comp. Biochem. Physiol., 114B, 145-151.

CIAVARRA R.P., GOLDMAN C., 1994. Heat stress induces hsc70/nuclear topoisomerase I complex formation in vivo: evidence for hsc70-mediated, ATP-independent reactivation in vitro. Proc. Natl. Acad. Sci. USA, 91, 1751-1755.

COZZARELLI N.R., 1980. DNA gyrase and the supercoiling of DNA. Science, 207, 953960.

FLEISCHMANN G., PFLUGFELDER G., STEINER E.K., JAVAHERIAN K., HOWARD G.C., WANG J.-C., ELGIN SCR., 1984. Drosophila DNA topoisomerase I is associated with transcriptionally active regions of the genome. Proc. Natl. Acad. Sci. USA, 81, 6958-6962.

GALANDE S., MUNIYAPPA K. 1996. Purification and functional characterization of type II DNA topoisomerase from rat testis and comparison with topoisomerase II from liver. Biochim. Biophys Acta, 1308, 58-66.

GILMOUR T., ELGIN S.C., 1987. Localization of specific topoisomerase I interactions within the transcribed region of active heat shock genes by using the inhibitor campothecin. Mol. Cell Biol., 7, 141-148.

GILMOUR D.S., PFLUGFELDER G., WANG J.C., LIS J.-T.., 1986. Topoisomerase I interacts with transcribed regions in Drosophila cells. Cell, 44, 401-407.

GOTOT., WANG J.C., 1985. Cloning of yeast TOP1, the gene encoding DNA topoisomerase I, and construction of mutants defective in both DNA topoisomerase I and DNA topoisomerase II. Proc. Natl. Acad. Sci. USA, 82, 7178-7182.

LIU L.F., LIU C.C., ALBERTS B.M., 1980. Type II DNA topoisomerases: enzymes that can unknot a topologically knotted DNA molecule via a reversible double-strand break. Cell, 19, 697-707.

LOPEZ-GARCIA P., FORTERRE P., 1999. Control of DNA topology during thermal stress in hyperthermophilic archea: DNA topoisomerase levels, activities and induced thermo tolerance during heat and cold shock in Sulfolobus. Mol. Microbiol., 33 (4), 766-77.

MCCLENNAN J.A., BOUBLIKOVA P., PALECEK E., 1990. Super helical torsion in cellular DNA responds directly to environmental and genetic factors. Proc. Natl. Acad. Sci. USA, 87, 8373-377.

POMMIER Y., KERRIGAN D., HERTMAN K.D., 1990. Phosphorilation of mammalian DNA topoisomerase I and activation by protein kinase C. J. Biol. Chem., 265, 9418-21.

ROCA J., MEZQUITA C., 1989. DNA topoisomerase II activity in nonreplicating, trancriptionally inactive, chicken late spermatids. EMBO J., 8, 1855-1860.

ROSE D., THOMAS W., HOLM C., 1990. Segregation of recombined chromosomes in meiosis I requires DNA topoisomerase II. Cell., 60, 1009-1017. 
SAMUELS D.S., SHIMIZU A., SHIMIZU N., 1989. Protein kinase C phosphorilates DNA topoisomerase I. FEBS Letters, 259, 57-70.

SANDER M., HSIEH T.S., 1983. Double strand DNA cleavage by type II DANN topoisomerase from Drosophila melanogaster. J. Biol. Chem., 258, 8421-8428.

UEMURA T., MORINO K., UZAWA A., SHIOZAKI K., YANAGIDA M., 1987. Cloning and sequencing of Schizosaccharomyces pombe DNA topoisomerase I gene, and effect of gene disruption. Nucleic Acid Res., 15, 9727-9739.

WANG J.C., 1987. Recent studies of DNA topoisomerases. Biochim. Biophys Acta, 909, $1-9$.

ZHANG C.X., CHEN A.D., GETTEL N.J., HSIEH T.-S., 2000. Essential functions of DANN topoisomerase I in Drosophila melanogaster. Develop. Biol., 222, 27-40. 